кУЛЬТУРОЛОГИЯ

DOI: $10.17805 /$ trudy.2015.3.8

\title{
СОВРЕМЕННЫЕ ТЕНДЕНЦИИ РАЗВИТИЯ ТУРИЗМА В РОССИИ КАК ФАКТОР ФОРМИРОВАНИЯ ПАТРИОТИЧЕСКОГО СОЗНАНИЯ МОЛОДЕЖИ
}

\author{
Ю. С. Путрик \\ (Московский гуманитарный университет)
}

Аннотация: В статье рассматриваются формы и методы патриотического воспитания молодежи России на основе вовлечения объектов культурного и природного наследия в современные туристские технологии.

Ключевые слова: туризм в России, патриотизм, культурное наследие, объекты культурного наследия, патриотическое сознание молодежи.

\section{CURRENT TRENDS IN THE DEVELOPMENT OF TOURISM IN RUSSIA AS A FACTOR IN BUILDING PATRIOTIC CONSCIOUSNESS OF THE YOUTH}

\author{
Yu. S. Putrik \\ (Moscow University for the Humanities)
}

Abstract: The article considers the forms and methods of patriotic education of Russia's youth by means of involving cutting-edge tourism technologies in covering cultural and natural heritage

Keywords: tourism in Russia, patriotism, cultural heritage, objects of cultural heritage, patriotic consciousness of the youth.

Патриотическое воспитание молодежи всегда было и остается важным направлением государственной политики России как необходимое условие обеспечения национальной безопасности Российской Федерации. Важной составляющей этой политики является подготовка молодежи к защите Родины. Начиная с 2001 года, постановлениями Правительства Российской Федерации каждые пять лет обновляется и вводится в действие Государственная программа патриотического воспитания граждан. В своем содержании Программа предусматривает единый комплекс мероприятий, направленных на дальнейшее совершенствование системы патриотического воспитания граждан России. На основе формирования патриотических чувств и патриотического сознания, программа призвана обеспечить решение задач по консолидации общества, по поддержанию социальной и экономической стабильности, по упрочению единства и дружбы народов многонациональной России.

Воспитание и поддержание патриотического сознания населения и молодежи сегодня происходит и за рамками упомянутых программ, 
которые не могут вместить весь спектр форм методов патриотического воздействия на население и выходят далеко за рамки собственно образовательного процесса. Открытость информационного пространства России, начиная с 90-х годов XX века, привела к воздействию на российское общество в том числе идей, идеологий, норм и стандартов других цивилизаций. Все это стало частью обострившейся в последнее время в мире проблемы межцивилизационного взаимодействия. Поэтому возникают задачи обеспечения противодействия антипатриотическим проявлением, подогреваемым с Запада методом применения так называемой «мягкой силы», когда устоявшиеся моральные и культурные российские ценности пытаются размывать в сознании населения и молодежи, заменяя их другими, низкопробными и псевдонравственными. Тем самым, по нашему мнению, сознание молодежи отрывается от базовых российских ценностей, вносятся все более серьезные помехи в процесс самоидентификации населения на предмет принадлежности к российскому обществу, российской культуре. Поэтому в современных условиях идеи патриотизма могут и должны в гораздо большей степени чем раньше опираться на богатейшее культурное и природное наследие нашей страны, расширяя тем самым базис формирования высоких, социально значимых чувств, убеждений, позиций и устремлений молодежи, воспитывая ее готовность и способность к активным действиям на благо Отечества. В этой связи заметно возрастает роль туризма и экскурсий как связующего звена и коммуникативного канала между отечественным наследием и молодежью, как способ более глубокого ознакомления и более полного приобщения молодежи к традиционным российским культурным и природным ценностям в ходе туристских поездок и походов по местам и объектам культурного и природного наследия Российской Федерации.

Так, в Федеральном законе от 24 ноября 1996 г. № 132-Ф3 «Об основах туристской деятельности в Российской Федерации» основными целями государственного регулирования туристской деятельности определены такие цели, как охрана окружающей природной среды; создание условий для деятельности, направленной на воспитание, образование и оздоровление туристов; сохранение объектов туристского показа, рациональное использование природного и культурного наследия (Федеральный закон ..., 1996: Электр. ресурс).

Основу историко-культурного и природного потенциала России составляют прежде всего такие объекты, как исторические поселения, музеи-усадьбы, музеи-заповедники, национальные и природные парки, заповедники и некоторые другие типы особо охраняемых природных территорий - всего более 1000 объектов, расположенных в самых разных частях нашей огромной страны и привлекающих туристов и экскурсан- 
тов. Культурное и природное наследие является важнейшим фактором сохранения как культурной идентичности народа, так и укрепления дружественных отношений между несколькими различными этносами, проживающими на территории одного государства, что является особенно важным для современного российского общества. Культурное наследие нашей полиэтнической страны сформировался как сумма вкладов, которые внес каждый из народов России. Объекты культурного и природного наследия создают предпосылки для сохранения самобытности народов России, они закрепляют многообразие национальных и религиозных культур, что, безусловно, способствует развитию патриотического сознания населения нашей страны (Путрик, 2008: 96).

Поэтому сегодня представляется весьма целесообразным и актуальным пристальное рассмотрение вопросов более активного вовлечения объектов культурного и природного наследия в процесс и систему патриотического воспитания молодежи. Выделяются наиболее эффективные методы и способы использования объектов культурного и природного наследия народов России в целях патриотического и нравственного воспитания молодежи, среди которых важное место занимает туризм и экскурсии с применение интерактивных технологий и подходов. В целях усиления эффективности воспитательно-патриотической деятельности особое внимание уделено взаимодействию таких жизненно важных сфер как сфера культуры, сфера образования и сфера туризма. В таком взаимодействии и взаимной интеграции кроются большие резервы всей воспитательно-патриотической деятельности.

Если учесть, что задачи патриотического воспитания молодежи заключаются в формировании самосознания, ценностного отношения к личности, к обществу, к идеалам, в приобщении к системе ценностей, отражающих богатство и своеобразие истории и культуры Отечества, то становится достаточно очевидным, что походы, поездки и экскурсии всегда вносили и вносят свой вклад в решение этих задач. В советский период самая разветвленная туристская организация - Центральный совет по туризму и экскурсиям ВЦСПС, - в ведении которой находились тысячи туристских и экскурсионных организаций и предприятий по всей стране, уделяла этим вопросам самое серьезной внимание. Деятельность туристских организаций по патриотическому воспитанию молодежи и населения в целом была постоянно в поле зрения всех республиканских и областных советов по туризму и экскурсиям. Так, в 1977 г. в отраслевом информационном издании сообщалось, что «Бюро Центрального совета по туризму и экскурсиям одобрило работу Новороссийского бюро путешествий и экскурсий Краснодарского краевого совета по туризму и экскурсиям по военно-патриотическому и интернациональному воспитанию 
трудящихся и учащейся молодежи и рекомендовало советам по туризму и экскурсиям при проведении Всесоюзного похода комсомольцев и молодежи по местам революционной, боевой и трудовой славы советского народа широко использовать организацию экскурсий, в содержании которых раскрывается советский патриотизм, дружба народов СССР, пролетарский интернационализм, руководящая роль КПСС в строительстве коммунистического общества» (Сборник информационных материалов, 1978: 3). Если отбросить идеологическую «начинку» подобных документов, видно, что работа по патриотическому воспитанию в сфере туризма велась системно и последовательно. В нее включались самые различные мероприятия и подходы, начиная с названия самих экскурсий («Городгерой, город-труженик», По местам боев на «Голубой линии», «Улицы пламенных лет» и др. На экскурсиях рассказывалось о массовом героизме советских воинов, их боевом товариществе, нерушимой дружбе народов СССР, партизанах, командирах, о девушках и юношах, сражавшихся наравне с взрослыми. Составной частью экскурсий было использование магнитофонных записей, просмотр хроникальных кинофильмов периода Великой Отечественной войны. Специальные экскурсии проводились для призывников. Важное место в работе Новороссийского бюро путешествий и экскурсий, как и сотен других экскурсионных по всей стране, занимало интернациональное воспитание на экскурсиях (там же).

В современных условиях глобализации и всеобщей информатизации спектр форм и методов патриотического воспитания в сфере туризма становится гораздо более разнообразным благодаря широкому вовлечению в этот процесс объектов культурного и природного наследия. Возрастанию эффективности воспитательно-патриотической работы способствует и ситуация, связанная с переориентацией, начиная с 2014 года, туристского потока наших сограждан на внутренние туристские маршруты по родной стране. Здесь объекты культурного и природного наследия начинают чаще посещаться туристами и экскурсантами, а особенно - в «ближнем туризме» по родному краю и краеведческих походах и, соответственно, играть все более значительную роль в воспитательном процессе. Возрастание роли объектов наследия в патриотическом воспитании полностью вписывается в развивающуюся в Российском НИИ культурного и природного наследия новую концепцию понимания наследия как ресурса развития человеческого потенциала регионов России и подразумевающую под целью культурной политики «...оказание влияния на качество локального человеческого потенциала» (Миронов, 2014: 7). Заметим при этом, что понятие объектов наследия в настоящее время получает все более широкую трактовку. Появляется понятие «религиозное наследие», которое рассматривается как «весьма эффективный способ трансляции культурных ценностей» (Житенев, 2014: 42). 
Объекты материального и нематериального наследия в той или иной форме присутствуют в большинстве коммуникационных каналов воздействия на формирование патриотического сознания молодежи: в телевизионных передачах, художественных произведениях литературы, живописи, театральных постановках. Это касается и музейной педагогики, и библиотечного дела, и самодеятельности молодежных объединений и других форм культурного воздействия на молодежь. Здесь, в большинстве перечисленных форм воздействия и восприятия объекты наследия представляются и подаются в опосредованном виде, как правило через авторское или режиссерское восприятие, что, безусловно, разнообразит и обогащает впечатление и информацию о тех или иных значимых объектах. При этом непосредственный контакт с объектами отсутствует. Он появляется в таких специфических формах деятельности, как краеведение, туризм, экскурсии в форме групповых и индивидуальных поездок к объектам природного или культурного наследия. В этом как раз и заключается особенность и глубина восприятия объекта в ходе непосредственного с ним ознакомления в процессе путешествия.

Известно, что объекты культурного и природного наследия являются одними из главных мотиваторов посещения тех или иных территорий и пунктов. А уже вокруг этих мотиваций строится вся остальная архитектура сервисных услуг, делающих эти посещения доступными, комфортными, безопасными, привлекательными, информативными и эстетичными. Наглядное и непосредственное восприятие объекта, да еще в сочетании не только с экскурсией, но и с различными мероприятиями на базе этих объектов (театрализованные представления, конкурсы, костюмированные фестивали, историческая реконструкция событий и т. п.) - наиболее эмоциональный и поэтому убедительный способ ознакомления с объектами в условиях конкретной местности, что в сочетании с поездкой делает эти впечатления незабываемыми и впоследствии составляет, как правило, значимую составляющую его культурного и духовного богатства личности. Именно поэтому туризм, экскурсии и краеведческие походы с учащимися традиционно использовались и используются в настоящее время в образовательных и воспитательных целях.

На современном этапе развития туризма в Российской Федерации, для которого характерным является быстрый рост внутреннего туризма, вопросы использования культурного и природного наследия в туристских программах получают новое звучание и возникают новые возможности значительно более широкого и интенсивного туристско-рекреационного посещения нашими согражданами тех или иных регионов. В 2014 г. внутренний туристский поток вырос на $30 \%$ и составил 41 млн туристов против 32 млн в 2013 г. Тенденция увеличения потока туристов в регионы и туристские центры России будет сохраняться и в ближайшие годы. Обстоя- 
тельств для этого несколько - внешних и внутренних, среди которых девальвация рубля, усиление патриотических настроений, присоединение Крыма к России. В целом же можно без всякого сомнения констатировать, что для пропаганды и продвижения культурного и природного наследия России средствами туризма ситуация сложилась очень благоприятная. Свою роль, безусловно, сыграли и плановые мероприятия Ростуризма в рамках выполнения федеральной целевой программы «Развитие внутреннего и въездного туризма в Российской Федерации (2011-2018 гг.)». Помогли и рекламные кампании олимпийского Сочи и присоединенного Крыма. Оба эти курорта оказались в 2014 г. на вершине медийного успеха.

В то же время важно понимать и учитывать при работе с молодежью, что современному потребителю туристского продукта уже далеко не всегда достаточно экскурсии в ее традиционном виде как формы ознакомления с культурой, историй и природой. У современного потребителя сформирована и все более явственно и массово проявляется потребность стать участником конкретного действия или события. Погружение в прошлое в интерактивном режиме пользуется неизменным спросом людей, посещающих исторические центры и местности с туристско-познавательными целями. И это сегодня все в больше и больше мере учитывается при формировании туристских продуктов той или иной дестинации. Поэтому здесь, безусловно, необходимо более тесное творческое и деловое взаимодействие между организаторами туризма и организаторами культурномассовых и сценическо-постановочных мероприятий. В эту же группу креативных мероприятий можно отнести и формирование проектов по подготовке планов и сценариев по воссозданию исторических и вероятных событий прошлых столетий, осуществляемых в форме исторических реконструкций и реставраций с привлечением волонтеров для массовых сцен и сопровождаемых фейерверками и лазерными шоу. Все это многократно усиливает впечатления от увиденного и прочувствованного. В этом как раз и заключается смысл и успешное развитие в последние годы в нашей стране событийного туризма. Людям, молодежи нужны мотивации для поездки в тот или иной регион. И когда создается событие, у человека появляется и мотивация поехать туда, куда раньше, быть может, он и не собирался ехать. В событийном туризме с особой силой проявляются интеграционные возможности сферы культуры, сферы образования и туризма. Построенные по принципу сочетания этих трех сфер события пользуются несомненным успехом и привлекают значительные массы туристов и посетителей. К ярким примерам таких мероприятий можно отнести фольклорно-музыкальный фестиваль, который ежегодно проводится уже более 30 лет в достопримечательном месте «Бежин луг» в Тульской области и собирающий ежегодно от 5 до 8 тысяч посетителей и туристов 
(Путрик, Ельчанинов, 2014: 110). Завоевывает все большую популярность музыкальный фестиваль «Классика над Волгой», организованный Ассоциацией событийного туризма недалеко от г. Тольятти на берегу р. Волга, когда для исполнения своих произведений в природном окружении приглашаются известные исполнители и целые ансамбли классической музыки.Этот фестиваль привлекает ежегодно сотни людей из различных регионов Российской Федерации. И таких примеров в различных регионах страны становится с каждым годом все больше.

Фестивали и события, связанные с искусством, русской культурой и поэзией с успехом могут проводиться и за рубежом. Так, в Сербии, в горном массиве Златый Бор на одном из замечательных курортов этой страны в природных условия проводится мероприятие под названием «Поэтические огни», когда в вечернее время в свете костров читаются стихи русских поэтов. Непосредственным участником и организатором этого мероприятия является нынешний глава рода Лермонтовых, полный тезка великого русского поэта, Михаил Юрьевич Лермонотов, доктор культурологии и Президент ассоциации «Лермонтовское наследие». Это мероприятие привлекает немалое число российских туристов, отдыхающих в Сербии, что, несомненно, способствует укреплению патриотического сознания у наших соотечественников.

Как видим, тенденции, направленные на вовлечение объектов культурного наследия в туристский оборот и соответственно - на формирование патриотического сознания молодежи получают в настоящее время все большее развитие, но требуют, безусловно, системной государственной поддержки.

\section{СПИСОК ЛИТЕРАТУРЫ}

Житенев, С. Ю. (2014) Религиозное наследие России: определение, состав, размещение и использование // Наследие и современность. Информационный сборник. Вып. № 21. М. : Издательство «Индрик». С. 37-50.

Миронов, А. С. (2014) Наследие как ресурс развития человеческого потенциала регионов России // Наследие и современность. Информационный сборник. Вып. № 21. М. : Издательство «Индрик». С. 5-15.

Путрик Ю. С., Ельчанинов А. И.(2014) Перспективы развития событийного туризма на объектах культурного наследия: на примере туристскорекреационного кластера «Бежин луг» Тульской области // Наследие и современность. Информационный сборник. Вып. № 21. М. : Издательство «Индрик». С. 105-119.

Путрик, Ю. С. (2008) Туризм как фактор сохранения наследия: исторический опыт и традиции // Вестник Томского государственного университета. № 311. С. 95-101.

Сборник информационных материалов (1978) / Центральный совет 
по туризму и экскурсиям ВЦСПС. Вып. 28. М. : ЦРИБ «Турист».

Федеральный закон Российской Федерации от 24 ноября 1996 г. №132Ф3 «Об основах туристской деятельности в Российской Федерации» (1996) [Электронный ресурс] // Российская газета. 3 декабря. URL: http://www. rg.ru/1996/12/03/osnovy-turizma-dok.html (дата обращения: 15.03.2015).

Путрик Юрий Степанович - доктор исторических наук, заведующий кафедрой социально-культурного сервиса и туризма Московского гуманитарного университета, профессор Международной Туристской Академии, вице-президент Российской Ассоциации социального туризма. Адрес: 111395, Россия, г. Москва, ул. Юности, д. 5. Тел.: +7 (499) 374-7956. Эл. адрес: putrik@list.ru

Putrik Yurii Stepanovich, Doctor of History, Chair, Department of social and cultural service and tourism, Moscow University for the Humanities; Professor, International Tourism Academy; Vice President, Russian Association of Social Tourism. Postal address: 5 Yunosti St., 111395, Moscow, Russian Federation. Tel.: +7 (499) 374-79-56. Email: putrik@list.ru 